\title{
Hubungan Tingkat Stres Dengan Peningkatan Kadar Gula Darah Pada Pasien Diabetes Mellitus Tipe 2 di Poli Penyakit Dalam RSUD Kabupaten Bintan Tahun 2019
}

\author{
Tatar Ina ${ }^{1}$, Rizki Sari Utami ${ }^{2}$, Siska Natalia ${ }^{3}$ \\ Program Studi Ilmu Keperawatan
}

STIKes Awal Bros Batam Jl. Abulyatam Kelurahan Belian Kecamatan Kota Batam Email : tatarina1980@gmail.com

\begin{abstract}
ABSTRAK
Menurut data RSUD Kabupaten Bintan tahun 2017 DM tipe 2 menduduki urutan tingkat pertama dalam sepuluh penyakit terbesar. Berdasarkan data pada tahun 2018 DM tipe 2 juga menduduki urutan pertama dalam sepuluh penyakit terbesar. Pada tahun 2019, menduduki urutan keempat Penelitian ini bertujuan untuk mengetahui hubungan tingkat stres dengan peningkatan kadar gula darah pada pasien diabetes mellitus tipe 2 di Poli Penyakit Dalam RSUD Kabupaten Bintan Tahun 2019 pada 02 Februari 2020 sampai dengan 08 Maret 2020. Rancangan penelitian ini adalah deskriptif kuantitatif dengan pendekatan cross sectional dengan metode pengambilan sampel dalam penelitian ini adalah total sampling. Yang berjumlah 85 orang pasien dan data dianalisa menggunakan uji chi-square. Hasil diketahui tingkat stres responden di Poli Penyakit Dalam RSUD Kabupaten Bintan tertinggi yaitu tingkat stres berat sebanyak 48 orang $(55,5 \%)$. Kadar gula darah responden di Poli Penyakit Dalam RSUD Kabupaten Bintan tertinggi yaitu kadar gula darah sedang sebanyak 80 orang $(70,6 \%)$. Hasil analisa didapatkan nilai pvalue $0,000 \leq 0,05$ berarti dapat disimpulkan ada perbedaan proporsi kadar gula darah responden yang mengalami stres ringan dengan yang mengalami stress sedang, artinya Ho ditolak dan Ha diterima (ada hubungan tingkat stres dengan peningkatan kadar gula darah pada pasien diabetes mellitus tipe 2 di Poli Penyakit Dalam RSUD Kabupaten Bintan Tahun 2019). Analisis keeratan hubungan dua variabel didapat $\mathrm{OR}=10,118$,. Penelitian ini diharapkan memberikan pendidikan kesehatan tentang cara perilaku hihup sehat dalam perawatan diri pasien Diabetes Melitus terutama DM tipe 2 memalui KIE (komunikasi, edukasi dan informasi)
\end{abstract}

Kata kunci : Tingkat Stres, Peningkatan Kadar Gula Darah Daftar Pustaka : 37 (2015-2018) 


\title{
Correlation between Stress Level and Increased Blood Sugar Level in Type 2 Diabetes Mellitus Patients in Internal Medicine Poly RSUD Bintan districts in 2019
}

\author{
Tatar Ina ${ }^{1}$, Rizki Sari Utami ${ }^{2}$, Siska Natalia ${ }^{3}$ \\ Nursing Study Program \\ STIKes Awal Bros Batam Jl. Abulyatam Kelurahan Belian Kecamatan Kota Batam \\ Email : tatarina1980@gmail.com
}

\begin{abstract}
According to data from the Bintan District Hospital in 2017 DM type 2 ranks first in the ten biggest diseases. Based on data in 2018 DM type 2 also ranks first in the ten biggest diseases. In 2019, ranks fourth This study aims to determine the relationship of stress levels with increased blood sugar levels in patients with type 2 diabetes mellitus in Internal Medicine Poly Bintan District Hospital in 2019 on February 022020 until March 08 2020. The design of this study is descriptive quantitative with cross sectional approach with the sampling method in this study is total sampling. A total of 85 patients and data were analyzed using the chisquare test. The results revealed that the stress level of respondents in the Internal Medicine Polyclinic of Bintan District was the highest level of severe stress as many as 48 people $(55.5 \%)$. The highest blood sugar level of respondents in the Internal Medicine Polyclinic of Bintan Regency was 80 people (70.6\%). The analysis results obtained a $p$ value of $0.000 \leq 0.05$ means it can be concluded that there is a difference in the proportion of respondents' blood sugar levels that are experiencing mild stress with those experiencing moderate stress, meaning Ho is rejected and $\mathrm{Ha}$ is accepted (there is a relationship between stress levels and increased blood sugar levels in patients with diabetes mellitus type 2 in Internal Medicine Poly Hospital of Bintan Regency in 2019). Analysis of the closeness of the relationship between the two variables obtained $\mathrm{OR}=10.118,$. This research is expected to provide health education about healthy living behavior in the selfcare of Diabetes Mellitus patients especially DM type 2 through IEC (communication, education and information)
\end{abstract}

Keywords $\quad$ : Stress Level, P Increased Blood Sugar Level

Bibliography : 37 (2015-2018)

PENDAHULUAN

Penyakit diabetes mellitus sangat berpengaruh terhadap kualitas sumber daya manusia dan berdampak pada peningkatan biaya kesehatan yang cukup besar. Oleh karenanya semua pihak, baik masyarakat maupun pemerintah, seharusnya ikut serta secara aktif dalam usaha upaya pencegahan. Diabetes mellitus merupakan penyakit menahun yang akan dialami seumur hidup. Pengelolaan penyakit ini memerlukan peran serta dokter, perawat, ahli gizi, dan tenaga kesehatan lain. Pasien dan keluarga juga mempunyai peran yang penting, sehingga perlu mendapatkan edukasi untuk memberikan pemahaman mengenai perjalanan penyakit, pencegahan, penyulit, dan penatalaksanaan diabetes mellitus (Eliana, 2015). 
Stres dan DM memiliki hubungan yang sangat erat dan berbagai penyakit yang sedang diderita menyebabkan penurunan kondisi seseorang hingga memicu terjadinya stres (Nugroho, 2017). Stres merupakan gangguan pada tubuh dan pikiran yang disebabkan oleh perubahan dan tuntutan kehidupan (Ardian, 2016). Takut, cemas, malu, dan marah merupakan bentuk lain emosi kehidupan yang penuh dengan stress akan berpengaruh terhadap fluktuasi glukosa darah meskipun telah diupayakan diet, latihan fisik maupun pemakaian obat obatan dengan secermat mungkin. UKPDS (United Kingdom Prospective Diabetes Study) menemukan dengan berjalannya waktu kadar glukosa darah penderita DM diperlihatkan akan tetap terus meningkat secara progresif, meskipun intervensi sudah dilakukan melalui perubahan gaya hidup, diet, olahraga dan obat-obatan (Izzati et all, 2015).

Menurut penelitian Meivi (2017) bahwa sebagian besar responden mengalami tingkat stres berat dan kadar gula darah buruk $(59,7 \%)$ dan ada hubungan antara tingkat stres dengan kadar gula darah pada pasien diabetes melitus tipe II di Rumah Sakit Pancaran Kasih GMIM Manado. Sedangkan menurut pendapat Damayanti (2015) Dalam kondisi normal sejumlah glukosa dari makanan akan bersirkulasi di dalam darah, kadar glukosa dalam darah di atur oleh insulin, yaitu hormon yang di produksi oleh pankreas, berfungsi mengontrol kadar glukosa dalam darah dengan cara mengatur pembentukan dan penyimpanan glukosa. Klien DM harus menyadari kemungkinan kemunduran pengendalian diabetes akibat stres yang mereka alami, sehingga gula darah mereka menjadi tinggi. Mereka perlu melakukan upaya-upaya untuk meningkatkan motivasi mereka agar sedapat mungkin mematuhi rencana terapi diabetes pada saat-saat stress (Smeltzer \& Bare, 2015).

Berdasarkan data dari Rekam Medis RSUD Kabupaten Bintan tahun 2017 DM tipe 2 menduduki urutan tingkat pertama dalam sepuluh penyakit terbesar. Berdasarkan data pada tahun 2018 DM tipe 2 juga menduduki urutan pertama dalam sepuluh penyakit terbesar. Pada tahun 2019, menduduki urutan keempat.

Berdasarkan studi pendahuluan Berdasarkan studi pendahuluan di Poli Penyakit Dalam RSUD Kabupaten Bintan dalam hal ini peneliti mewancarai 10 orang penderita diabetes mellitus tipe 2 , di dapatkan bahwa 4 pasien mengatakan sering memeriksakan kadar gula darah namun tetap saja tidak ada perubahan kadang naik kadang turun sehingga menjadi beban fikiran, 3 pasien mengatakan tidak percaya diri dengan kemampuan sehari hari saya untuk menangani diabetes, 3 pasien pasien mengatakan pikiran terganggu karena memikirkan akan mengalami komplikasi jangka panjang yang serius, tidak peduli apa saja yang telah saya lakukan.

Berdasarkan latar belakang diatas, maka peneliti tertarik untuk melakukan penelitian tentang "Hubungan Tingkat Stres Dengan Peningkatan Kadar Gula Darah Pada Pasien Diabetes Mellitus Tipe 2 di Poli Penyakit Dalam RSUD Kabupaten Bintan Tahun 2019”.

\section{METODELOGI PENELITIAN}

Jenis penelitian yang digunakan pada penelitian ini adalah 
deskriptif kuantitatif dengan pendekatan cross sectional. Penelitian ini bertujuan untuk menganalisa hubungan tingkat stres dengan peningkatan kadar gula darah pada pasien diabetes mellitus tipe 2 di Poli Penyakit Dalam RSUD Kabupaten Bintan. Pada penelitian ini sebagai populasinya adalah seluruh pasien rawat jalan di Poli Penyakit Dalam di RSUD Kabupaten Bintan dalam kurun waktu 1 bulan yang rata-ratanya 85 pasien. Pada penelitian ini, peneliti menggunakan teknik sampel jenuh atau total sampling yaitu teknik penentuan sampel dengan cara mengambil seluruh anggota populasi sebagai responden atau sampel yaitu 85 orang.

\section{HASIL PENELITIAN}

Berdasarkan hasil penelitian, diperoleh karakteristik responden yang meliputi umur, jenis kelamin, pendidikan terakhir, dan lama penyakit dapat dilihat pada tabel dibawah ini:

\section{Karakteristik Responden}

Tabel 4.1 Karakteristik Responden Berdasarkan Usia, Jenis Kelamin, Pendidikan, dan Pekerjaan di Poli Penyakit Dalam RSUD Kabupaten Bintan Tahun 2019

\begin{tabular}{cccr}
\hline NO & $\begin{array}{c}\text { Karakteristik } \\
\text { Responden }\end{array}$ & f & \% \\
\hline $1 \quad$ Usia & & \\
& $-<45$ Tahun & 1 & 1,2 \\
& $\quad-45-60$ Tahun & 43 & 50,6 \\
& $\quad-\geq 60$ Tahun & 41 & 48,2 \\
& $\quad$ Total & $\mathbf{8 5}$ & $\mathbf{1 0 0}$ \\
& Jenis Kelamin & & \\
& a. Laki-Laki & 47 & 55,3 \\
& b. Perempuan & 38 & 44,7 \\
& $\quad$ Total & $\mathbf{8 5}$ & $\mathbf{1 0 0}$
\end{tabular}

\begin{tabular}{|c|c|c|c|}
\hline \multirow[t]{11}{*}{3} & \multicolumn{3}{|l|}{ Pendidikan } \\
\hline & a. Tidak Sekolah & 5 & 5,9 \\
\hline & b. SD & 26 & 30,6 \\
\hline & c. SMP & 35 & 41,2 \\
\hline & d. SMA & 14 & 16,5 \\
\hline & e. Perguruan Tinggi & 5 & 5,9 \\
\hline & Total & 85 & 100 \\
\hline & Lama Penyakit & & \\
\hline & a. $\leq 5$ Tahun & 32 & 37,6 \\
\hline & b. > 5tahun & 53 & 62,4 \\
\hline & Total & 85 & 100 \\
\hline
\end{tabular}

Berdasarkan tabel 4.1 di atas dapat dilihat bahwa responden yang dilakukan wawancara sebanyak 85 orang. Usia responden adalah yang berusia 45-60 tahun (50,6\%). Dengan responden tertinggi adalah laki-laki dengan jumlah 47 orang $(55,3 \%)$. Dalam penelitian ini, pendidikan responden tertinggi adalah SMP dengan kumulatif sebanyak 35 responden $(41,2 \%)$. Sedangkan berdasarkan lama penyakit adalah lebih dari 5 tahun sebanyak 53 responden $(62,4 \%)$

\section{ANALISA UNIVARIAT}

Tabel 4.2 Distribusi Frekuensi Tingkat Stres Responden di Poli Penyakit Dalam RSUD Kabupaten Bintan Tahun 2019

\begin{tabular}{ccc|c} 
No & Tingkat Stres & f & \% \\
\hline 1 & Normal & 0 & 0 \\
\hline 2 & Sedang & 37 & 43,5 \\
\hline 3 & Berat & 48 & 56,5 \\
\hline & Jumlah & $\mathbf{8 5}$ & $\mathbf{1 0 0}$ \\
\hline
\end{tabular}

Berdasarkan Tabel 4.2. diatas dapat dilihat bahwa tingkat stres responden di Poli Penyakit Dalam RSUD Kabupaten Bintan tertinggi yaitu tingkat stres Berat sebanyak 48 orang $(56,5 \%)$ dan terendah yaitu stres sedang adalah 37 orang $(43,5 \%)$.

Tabel 4.3 Distribusi Frekuensi Kadar Gula Darah Responden di Poli Penyakit Dalam RSUD Kabupaten Bintan Tahun 2019

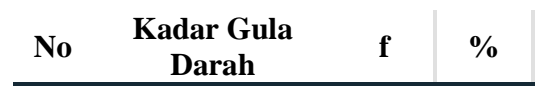




\begin{tabular}{clc|c}
\hline 1 & Normal & 25 & 29,4 \\
\hline 2 & Sedang & 60 & 70,6 \\
\hline 3 & Tinggi & 0 & 0 \\
\hline & Jumlah & $\mathbf{8 5}$ & $\mathbf{1 0 0}$ \\
\hline
\end{tabular}

Berdasarkan Tabel 4.3 diatas dapat dilihat bahwa kadar gula darah responden di Poli Penyakit Dalam RSUD Kabupaten Bintan tertinggi yaitu kadar gula darah sedang sebanyak 80 orang $(70,6 \%)$ dan terendah yaitu gula darah normal adalah 25 orang $(29,4 \%)$.

\section{Analisis Bivariat}

Hubungan tingkat stres dengan peningkatan kadar gula darah dapat dilihat pada tabel dibawah ini:

Tabel 4.4 Hubungan Tingkat Stres Dengan Peningkatan Kadar Gula Darah Pada Pasien Diabetes Mellitus Tipe 2 di Poli Penyakit Dalam

RSUD Kabupaten Bintan Tahun 2019

\begin{tabular}{llccccccc}
\hline No & Tingkat & \multicolumn{4}{c}{ Kadar Gula Darah } & Jumlah & Nilai \\
\cline { 3 - 6 } & Stres & \multicolumn{2}{c}{ Normal } & \multicolumn{2}{c}{ Sedang } & & & p value \\
& & $\mathrm{n}$ & $\%$ & $\mathrm{n}$ & $\%$ & $\mathrm{n}$ & $\%$ & \\
\hline 1. & Sedang & 20 & 80 & 17 & 28,3 & 37 & 43,5 & 0.000 \\
2. & Berat & 5 & 20 & 43 & 71,6 & 48 & 56,5 & \\
\hline & Jumlah & 25 & 29,4 & 60 & 70,5 & 85 & 100 & \\
\hline
\end{tabular}

Berdasarkan tabel 4.4 dapat diketahui bahwa dari 85 responden sebagian besar responden tingkat stres sedang kadar gula darah normal ada $80 \%$, hanya 28,33 yang kadar gula darahnya sedang dan sebagian besar responden tingkat stres berat kadar gula darah sedang ada $71,6 \%$, hanya $20 \%$ yang kadar gula darahnya baik. Hasil uji statistik chi-square didapatkan nilai pvalue $0,000 \leq 0,05$ berarti dapat disimpulkan ada perbedaan proporsi kadar gula darah responden yang mengalami stres ringan dengan yang mengalami stress sedang, artinya Ho ditolak dan $\mathrm{Ha}$ diterima (ada hubungan tingkat stres dengan peningkatan kadar gula darah pada pasien diabetes mellitus tipe 2 di Poli Penyakit Dalam RSUD Kabupaten Bintan Tahun 2019).

\section{PEMBAHASAN}

Berdasarkan hasil uji statistik chiBerdasarkan hasil uji statistik chisquare didapatkan nilai $\mathrm{p}$ value $0,000 \leq 0,05$ berarti dapat disimpulkan ada perbedaan proporsi kadar gula darah responden yang mengalami stres ringan dengan yang mengalami stress sedang, artinya Ho ditolak dan Ha diterima (ada hubungan tingkat stres dengan peningkatan kadar gula darah pada pasien diabetes mellitus tipe 2 di Poli Penyakit Dalam RSUD Kabupaten Bintan Tahun 2019). Analisis keeratan hubungan dua variabel didapat $\mathrm{OR}=10,118$.

Secara keseluruhan hasil penelitian ini menunjukkan bahwa responden di Poli Penyakit Dalam RSUD Kabupaten Bintan memiliki tingkat stres yang tingkat stres ringan yang mengalami peningkatan kadar gula darah kategori sedang. Hal ini berarti tingkat stres mempengaruhi peningkatan kadar gula darah pada pasien diabetes mellitus tipe 2 .

Hipotesis yang dapat diterima terkait dengan hubungan tersebut adalah adanya reaksi fisiologi terhadap stres yang dapat mempengaruhi kadar gula darah (Ermawati Dalami,2016). Stres secara psikologis maupun fisik memberikan dampak negatif terhadap pengendalian diabetes karena peningkatan hormon "stres" akan meningkatkan kadar glukosa darah, khususnya bila asupan makanan dan pemberian insulin yang tidak terkontrol.

Disamping itu, pada saat terjadi stres psikologis, penderita diabetes dapat mengubah pola makan, latihan dan penggunaan obat yang biasanya dipatuhi menjadi diabaikan oleh 
penderita. Keadaan ini akan menimbulkan hiperglikemia atau bahkan hipoglikemia. Sehingga apabila penderita diabetes mellitus mengalami stres, maka akan berpengaruh terhadap kadar gula darahnya.

Hal ini sama dengan penelitian yang dilakukan oleh Feby (2013) Berdasarkan hasil penelitian didapatkan pengaruh yang signifikan antara stress terhadap kadar gula darah sewaktu. Selanjutnya melihat arah korelasi dari variabel stress dan GDS tersebut karena angka koefisien korelasi bernilai positif (+) yakni 0,865 , maka hubungan kedua variabel merupakan hubungan yang searah. Searah artinya jika variabel stress nilainya tinggi, maka variabel GDS juga tinggi dan begitu pula sebaliknya.

Seperti halnya dengan penelitian Risma (2015) menemukan klien DM tipe 2 mengalami gejala stress yang diakibatkan oleh penyakit DM tipe 2 . Stresor akibat penyakit kronis ini merupakan tantangan terhadap kemampuan klien untuk tetap mempertahankan keseimbangan emosi dan kepuasan diri. Gangguan pada keseimbangan ini menyebabkan stress.

Hubungan tingkat stress dengan tingkat kadar gula darah penderita diabetes dijelaskan bahwa selain mengalami kemunduran dari segi fisik, seorang penderita diabetes melitus pada umumnya juga mengalami kemunduran dari segi emosinal. Segi emosional tersebut meliputi sikap menyangkal, obsesif, marah, dan takut yang semuanya merupakan sikap yang Nampak negatif.banyak yang menyangkal sewaktu dirinya menyandang diabetes dan tidak mau menerima kenyataan bahwa dia harus menjalani kehidupan sebagai penyandang diabetes.bahkan ada penyandang diabetes yang memerlukan beberapa tahun sampai ia mau mengubah cara hidupnya.

Menurut asumsi peneliti, penderita diabetes melitus pada umumnya juga mengalami kemunduran dari segi emosinal dan masih ada yang menyangkal. Menurut peneliti juga pasien sering memeriksakan kadar gula darah namun tetap saja tidak turun dikarenakan ada yang tidak mengkonsumsi obat secara teratur. Dari penelitian didapatkan bahwa perasaan stress psikologis dengan reaksi putus asa menyebabkan aktivitas aksis HPA (HopithalamusPituitary-Adrenal). Hal ini akan menyebabkan abnormalitas endokrin, termasuk meningginya kadar kartisol dan menurunnya kadar steroid seks. Ketidakseimbangan hormonal ini juga menyebabkan pelemahan organorgan dalam yang berperan dalam penyakit diabetes dan kardiovaskuler yang menyebabkan berkembangnya resistensi insulin

\section{KESIMPULAN DAN SARAN KESIMPULAN}

1. Tingkat stres responden di Poli Penyakit Dalam RSUD Kabupaten Bintan tertinggi yaitu tingkat stres berat sebanyak 48 orang $(55,5 \%)$

2. Kadar gula darah responden di Poli Penyakit Dalam RSUD Kabupaten Bintan tertinggi yaitu kadar gula darah sedang sebanyak 80 orang $(70,6 \%)$

3. Hasil analisa didapatkan nilai pvalue $0,000 \leq 0,05$ berarti dapat disimpulkan ada perbedaan proporsi kadar gula darah responden yang mengalami stres ringan dengan yang mengalami 
stress sedang, artinya Ho ditolak dan $\mathrm{Ha}$ diterima (ada hubungan tingkat stres dengan peningkatan kadar gula darah pada pasien diabetes mellitus tipe 2 di Poli Penyakit Dalam RSUD Kabupaten Bintan Tahun 2019). Analisis keeratan hubungan dua variabel didapat $\mathrm{OR}=10,118$

\section{SARAN}

1. Bagi Perawat

a. Memberikan edukasi kepada pasien tentang pola hidup sehat

b. Memberikan motovasi kepada keluarga untuk memberikan dukungan secara penuh pada penderita Diabetes Melitus tipe 2 dalam menjalani diet dan perawatan.

2. Bagi Rumah Sakit

a. Meningkatkan upaya tindakan preventif terhadap penyakit Diabetes Melitus tipe 2 malaui program pendidikan kesehatan kepada masyarakat dengan malakukan penyuluhan kesehatan maupun promosi kesehatan tentang Diabetes.

b. Bagi pasien yang sudah menderita, rumah sakit diharapkan memberikan pendidikan kesehatan tentang cara perilaku hihup sehat dalam perawatan diri pasien Diabetes Melitus terutama DM tipe 2 memalui KIE (komunikasi, edukasi dan informasi).

3. Bagi Ilmu Keperawatan

a. Hasil penelitian ini dapat dijadikan bahan tambahan referensi kepustakaan yang berguna untuk mengembangkan penelitain tentang materi dukungan sosial dan stress.

b. Menjadi bahan tambahan informasi tentang upaya penanganan stress emosional pasien pada pasien Diabetes Melitus dapat dilakukan dengan memberikan dukungan sosial.

\section{Bagi Peneliti}

Meningkatkan wawasan dan pengetahuan tentang dukungan sosial dan stress emosional yang dapat diterapkan kelak dalam pemberian asuhan keperawatan atau untuk mengembangkan kajian dan penelitian ilmiah.

5. Bagi Pasien DM tipe 2

Bersikap menerima atas penyakit yang diderita, sehingga dapat menjalani terapi dan perawatan dengan kesadaran tanpa beban sehingga tidak menimbulkan stress yang berlebihan.

6. Bagi Peneliti Selanjutnya

Dapat mengembangkan penelitian pada sample yang lebih luas dan pada variabel lain yang mempengaruhi stress emosional pasien seperti umur, pendidikan, sosial ekonomi, pekerjaan dan komplikasi

DAFTAR PUSTAKA

American Diabetes Association. (2016). $2016 \quad$ American Diabetes Association (ADA)

Diabetes Guidelines Summary Recommendation from NDEI. National Diabetes Education Initiative.

Ardian, I. (2016). Konsep Spiritualitas dan Religiusitas (Spiritual and Religion) dalam Konteks Keperawatan Pasien Diabetes Melitus Tipe 2. Jurnal Keperawatan Dan Pemikiran Ilmiah. 
Auliana, A., Yunir, E., Putranto, R., \& Nugroho, P. (2017). Pengaruh Depresi Terhadap Perbaikan Infeksi Ulkus Kaki Diabetik. Jurnal Penyakit Dalam Indonesia. https://doi.org/10.7454/jpdi.v2i4 .88

Bayuningtyas, R. Z., Verawati, M., \& Nasriati, R. (2018). Tingkat Depresi Pada Pasien Diabetes Mellitus Tipe 2 Di Poli Penyakit Dalam RSUD Dr. Harjono Ponorogo. Health Sciences Journal.

https://doi.org/10.24269/hsj.v2i 2.154

Edwina, D. A., Manaf, A., \& Efrida. (2015). Pola Komplikasi Kronis Penderita Diabetes Melitus Tipe 2 Rawat Inap di Bagian Penyakit Dalam RS. Dr. M. Djamil Padang Januari 2011 Desember 2012. Jurnal Kesehatan Andalas.

El Khoury, P., Roussel, R., Fumeron, F., Abou-Khalil, Y., Velho, G., Mohammedi, K., ... Hansel, B. (2018). Plasma proproteinconvertase-subtilisin/kexin type 9 (PCSK9) and cardiovascular events in type 2 diabetes. Diabetes, Obesity and Metabolism.

https://doi.org/10.1111/dom.131 81

Eliana, F. (2015). Penatalaksanaan DM Sesuai Konsensus Perkeni 2015. SATELIT SIMPOSIUM 6.1 DM UPDATE DAN HblC.

Guyton, C., \& Hall, J. (2016). Anatomi dan Fisiologi. Elsevier. https://doi.org/10.1007/s12369009-0019-1

Hawari, Dadang. (2018). Manajemen Stres Cemas dan Depresi. Jakarta: Balai Penerbit FKUI

Iroth, G. S. N., Kandou, G. D., \& Malonda, N. S. H. (2017). Hubungan antara umur dan pola makan dengan kejadian diabetes mellitus tipe 2 pada pasien rawat jalan di wilayah kerja puskesmas di sulawesi utara. EJournal Health.

Izzati, W., \& . N. (2015). Hubungan Tingkat Stres Dengan Peningkatan Kadar Gula Darah Pada Pasien Diabetes Mellitus Di Wilayah Kerja Puskesmas Perkotaan Rasimah Ahmad Bukittinggi Tahun 2015. 'AFIYAH.

Kamal, R. H., Novendrianto, D., Chadijah, F., Prasetya, G. B., Pratama, G. S., Ariadnya, M. O., ... Prajitno, J. H. (2017). Diabetes Risk Factor Scr In Adults Using $F$ Questionnaire And Oral Glucose Tolerance Test In Socah County, Bangkalan. Folia Medica Indonesiana. https://doi.org/10.20473/fmi.v5 3i3.6448

Katzung, B., \& Trevor, A. (2015). Katzung's Basic \& Clinical Pharmacology. Basic and Clinical Pharmacology.

Kaur, N., Kishore, L., \& Singh, R. (2016). Antidiabetic effect of new chromane isolated from Dillenia indica L. leaves in 
streptozotocin induced diabetic rats. Journal of Functional Foods.

https://doi.org/10.1016/j.jff.201

6.02 .016

Khonsary, S. (2017). Textbook of Medical Physiology. Surgical Neurology International. https://doi.org/10.4103/sni.sni_3 27_17

Kronenberg, Z. N., Osborne, E. J., Cone, K. R., Kennedy, B. J., Domyan, E. T., Shapiro, M. D., ... Yandell, M. (2015). Type 2 Diabetes Mellitus. In :Melmed, S, Polonsky, K. S., Larsen,. WILLIAMS Textbook of Endocrinology, 12th ed. Elsevier:1379

Lailatussifa, R., Husni, A., \& Nugroho, A. E. (2016). Antistress activity of Sargassum polycystum extracts using a cold restraint stress model. Food Science and Biotechnology. https://doi.org/10.1007/s10068016-0082-y

Mintarsih, W. Penyelenggaraan Lampung: (2017). Lampung.

Praktikum, Universitas

Muhith, A. (2015). Pendidikan Keperawatan Jiwa Teori dan Aplikasi. In Pendidikan Keperawatan Jiwa Teori dan Aplikasi.

Murray, R. K., Granner, D. K., Mayes, P. A., \& Rodwell, V. W. (2018). Biokimia Harper ed. 25. Jakarta: EGC. P.236-239.
Musradinur. (2016). Stres Dan Cara Mengatasinya Dalam Perspektif Psikologi. Jurnal Edukasi.

Nursalam. (2017). Metodologi Penelitian Ilmu Keperawatan: Pendekatan Praktis. Metodologi Penelitian Ilmu Keperawatan: Pendekatan Praktis.

Randall, D., Thomas, M., Whiting, D., \& McGrath, A. (2017). HARS. Journal of DM

Roberts, E. A., Herder, M., \& Hollis, A. (2015). Fair pricing of old orphan drugs: Considerations for Canada's orphan drug policy. CMAJ. https://doi.org/10.1503/cmaj.14 0308

Rudi, A., \& Kwureh, H. N. (2017). Faktor Risiko yang Mempengaruhi Kadar Gula Darah Puasa pada Pe Layanan Labora Wawasan Kesehatan.

Sangavi, R., \& Bennal, A. (2018). Evaluation of Coagulation Disturbances in Patients with Polycystic Ovary Syndrome. Indian Journal of Obstetrics and Gynecology. https://doi.org/10.21088/ijog.23 21.1636.6318.15

Sender, K., \& Decherney, P. (2016). Stuart Hall lives: cultural studies in an age of digital media. Critical Studies in Media Communication. https://doi.org/10.1080/1529503 6.2016 .1244725

Sherwood, L. (2015). Fisiologi manusia : dari sel ke sistem. 
Edisi 8. Jakarta: EGC 4

Soegondo, S. (2015). Diagnosis dan

Klasifikasi Diabetes Melitus

Terkini. In Penatalaksanaan

Diabetes Melitus Terpadu Edisi

Kedua.

Sugiyono. (2016a). Metode

Penelitian Kuantitatif, Kualitatif

dan Kombinasi (Mixed

Methods). Bandung: Alfabeta.

https://doi.org/Doi

10.1016/J.Datak.2004.11.010

Sugiyono, P. D. metode penelitian kuantitatif, kualitatif,dan R\&D. , Alfabeta, cv. (2016).

Sujarweni, V. W. (2015). SPSS untuk Penelitian. In SPSS untuk Penelitian.

Suyono, S. (2015). Patofisiologi Diabetes Melitus.

Penatalaksanaan Diabetes Melitus Terpadu Edisi Kedua. https://doi.org/10.1080/1093452 0009377048

Tjokroprawiro, askandar. (2015). Buku ajar ilmu penyakit dalam. Ed.2: Fakultas Kedokteran Universitas ... - Google Buku.

Wicaksono, S., \& Fajriyah, N. N. (2018). Hubungan Keaktifan dalam Klub Prolanis Terhadap Peningkatan Kualitas Hidup Diabetisi Tipe 2. Jurnal Ilmiah Kesehatan (JIK). 
